\title{
UDC 004.05
}

\section{EXPERT QUALITY EVALUATION OF INNOVATIVE SOFTWARE PRODUCTS: FORMATION OF THE MULTI-CRITERIA SYSTEM}

\author{
Larin Sergey Nikolaevich \\ leading researcher, $\mathrm{PhD}$ in technical sciences
}

Khroustalev Oleg Evguenievich senior researcher, $\mathrm{PhD}$ in economic sciences Central Economic \& Mathematic Institute of RAS, Moscow

\begin{abstract}
The article presents an approach to solving the problem of assessing the quality of modern information systems and innovative software products. The composition of criteria and basic quality indicators that allow evaluating the quality of information systems and innovative software products is determined. Quantitative values of these indicators can be obtained using the appropriate mathematical tools. Therefore, to assess the quality of information systems and innovative software products, it is proposed to use a multi-criteria expert system and mathematical tools using weighting coefficients of indicators and point estimates of their variable values. The proposed approach can be used to assess the quality of almost any information systems and innovative software products.
\end{abstract}

Key words: information system, innovative software project, quality evaluation, multi-criteria expert system, mathematical tools.

\section{ЭКСПЕРТНАЯ ОЦЕНКА КАЧЕСТВА ИННОВАЦИОННЫХ ПРОГРАММНЫХ ПРОДУКТОВ: ФОРМИРОВАНИЕ МНОГОКРИТЕРИАЛЬНОЙ СИСТЕМЫ}

\section{Ларин Сергей Николаевич}

ведущий научный сотрудник, кандидат технических наук

Хрусталев Олег Евгеньевич

старший научный сотрудник, кандидат экономических наук Центральный экономико-математический институт РАН, Москва

Аннотация: В статье представлен подход к решению проблемы оценки качества современных информационных систем и инновационных 
программных продуктов. Определен состав критериальных и основных показателей качества, которые позволяют выполнить оценку качества информационных систем и инновационных программных продуктов. Количественные значения этих показателей можно получить при помощи соответствующего математического инструментария. Поэтому для оценки качества информационных систем и инновационных программных продуктов предлагается использовать многокритериальную экспертную систему и математический инструментарий с применением весовых коэффициентов показателей и балльных оценок их переменных значений. Предложенный подход может применяться для оценки качества практически любых информационных систем и инновационных программных продуктов.

Ключевые слова: информационная система, инновационный программный проект, оценка качества, многокритериальная экспертная система, математический инструментарий.

\section{Introduction}

The rapid development of the knowledge economy and its rapid digitalization have predetermined the need for active development and implementation of modern information systems and innovative software products (ISP) in almost all spheres of society's life. It is no coincidence that today they occupy a leading position in the management systems of many enterprises. The effective use of information systems and ISP currently allows them to gain serious competitive advantages and strengthen their position in the markets. However, the will to accelerate the development, purchase and implement into production activities effective at first glance information systems and ISP often leads to failures and deterioration of results compared to those that were before their application. According to statistics, only $10 \%$ of the developed information systems and ISP satisfy customers fully. There are many reasons for this, and one of them is the poor quality of information systems and ISP.

Until recently, the responsibility for the quality of the developed information systems and ISP fell, as a rule, on their developers. The customer could, as a last resort, prescribe any requirements in the terms of reference. The biggest problem in assessing the quality of information systems and ISP was to formulate clear requirements for the composition of qualitative indicators and then determine their quantitative values.

The article hereunder offers one of approaches, allowing to obtain the real quality evaluation with reference to modern information systems and ISP. 


\section{Research purpose}

The purpose of this research is to substantiate the approach, allowing to obtain the real quality evaluation of modern information systems and ISP.

\section{Material and methods}

Even a brief description of the essence of the criteria and basic indicators of the quality of information systems and ISP makes it possible to freely abstract on a wide range of issues of assessing their quality. This is important in two complementary ways. Firstly, the justification of the choice of criteria and basic indicators that are more important for the successful functioning of information systems and ISP allows us to detail a lot of issues related to solving real problems of quality assessment. Secondly, since this detail is complex, it reduces the risk of incorrect solution of a number of important issues related to the mutual dependence of the selected indicators $[1,2,3]$.

In general, the ISO/IEC 25010:2011 standard [4] and its Russian counterpart GOST R ISO/IEC 25010-2015 [5] describe with a high level of detail a model for evaluating the quality of information systems and ISP and the software used in them with a small number of criteria and basic quality indicators. At the same time, each criterion or main indicator describes the degree of quality of a functional indicator in such detail that it makes it possible to obtain its quantitative value. This approach significantly facilitates the assessment of the quality of information systems and ISP, and the criteria and basic quality indicators themselves allow us to fully assess the quality of a particular functional indicator. This makes it possible to assess the quality of information systems and ISP and those used in them for any complexity.

Taking into account the complex structure of information systems and ISP and the software used in them, we will use those indicators that are able to meet the requirements of their potential users as their criteria and main quality indicators. In accordance with this, it is necessary to measure and control:

- quality features of the functioning of the hardware information systems and ISP, as well as of the used software;

- quality features of information systems and ISP, as well as of the used software;

- quality features of data management subsystems, with which information systems and ISP as well as the used software is used;

- quality features of the functioning of the network infrastructure of information systems and ISP, as well as of the used software; 
- personal and psychological peculiarities of employees, working with information systems and ISP, as well of the used software.

The process of evaluating the quality of information systems and ISP and the software used in them is inextricably linked with determining the values of indicators that can be measured and in which the consumer is interested. Modern methods of quality assessment have at their disposal a wide arsenal of measurement tools, among which the applied statistical data analysis, expert assessment methods, as well as more complex methods of data mining, such as neural networks, machine learning methods, etc. are particularly distinguished. They are covered in sufficient detail in the works of J. Giarratano and G. Riley [6], V. A. Zalyazhnykh and A.V. Girik [7], T. F. Moiseeva [8], Yu. V. Sidelnikov and S. A. Saltykov [9, P. 49], as well as in the monograph edited by K. Anders Ericsson [10].

Here are most typical features of the mathematical tool, used for these purposes:

1) tasks of measurements of criteria and basic quality indices are based on needs of an object domain, not only of mathematics itself;

2) various assumptions are inherent in the performance of measurements of criteria and basic quality indicators, which may differ from the strict apparatus of mathematical statistics;

3) considerable attention is paid to collecting data for their analysis and processing in order to detect format violations, abnormal values, omissions, etc.

The need to make objective measurements and obtain quantitative estimates of various quality characteristics of information systems and ISP and the software used in them requires the use of a certain measurement system and evaluation methods. Under the measurement system of criteria and basic indicators of the quality of information systems and ISP and the software used in them, we will understand a certain set of indicators that can be measured using various measuring scales, their characteristic units of measurement and certain relationships between them. The measurement scales used determine the range of values of the measured indicators with a given accuracy and in established units $[11,12]$.

\section{Results and discussion}

Practice shows that the effectiveness of quality assessment increases when using the creative activity of experts, with the help of which the construction of the most adequate and complete models of objects is achieved, the quality of which is then measured. Therefore, to assess the quality of information systems and ISP, it is proposed to use a multi-criteria expert system, which includes the following set of criteria indicators: 
- organizational maintenance level $\left(\mathrm{y}_{\mathrm{OM}}\right)$,

- technical maintenance level $\left(\mathrm{Y}_{\mathrm{TO}}\right)$

- mathematical maintenance level $\left(\mathrm{y}_{\mathrm{MM}}\right)$.

For each of these indices is established the set of basic indices, detailing its value, such as:

- for the organizational maintenance level $\left(\mathrm{y}_{\mathrm{OM}}\right)$ :

a) preparation of the initial data;

b) use of the initial data;

c) resistance to violations;

d) ratio between the number of optimization tasks and its total number;

- for the technical support level $\left(\mathrm{y}_{\mathrm{TO}}\right)$ :

a) average level of the computer load per day;

b) connection with the periphere;

c) display used;

- for the mathematical maintenance level ( $\left.\mathrm{y}_{\mathrm{MM}}\right)$ :

a) computer type;

b) software;

c) used software system.

The following formula can be used for the calculation of above mentioned private indices:

$\mathrm{y}_{\mathrm{OM}}=\mathrm{m}_{\mathrm{p}} \times \Sigma \mathrm{d}_{\mathrm{OMi}} \times \mathrm{y}_{\mathrm{OMi}}$

$\mathrm{y}_{\text {TO }}=\mathrm{m}_{\mathrm{p}} \times \Sigma \mathrm{d}_{\text {TOi }} \times \mathrm{y}_{\text {TOi }}$

$\mathrm{y}_{\mathrm{MM}}=\mathrm{m}_{\mathrm{p}} \times \Sigma \mathrm{d}_{\mathrm{MMi}} \times \mathrm{y}_{\mathrm{MMi}}$

where $\mathrm{m}_{\mathrm{p}}$ is a variable feature of the used method for the design of information systems and ISP;

$\mathrm{d}$ - weight parameters of the quality level of information systems and ISP;

$y$ - the grade evaluation of the given index of the quality level of information systems and ISP.

Following guide values are established for the variable value of the used ISP design method:

- when using the automated design $\mathrm{m}_{\mathrm{p}}=1,0$;

- when using typical project solutions $\mathrm{m}_{\mathrm{p}}=0,8$;

- when using prototypes $\mathrm{m}_{\mathrm{p}}=0,7$;

- when using the original design $m_{p}=0,6$;

Values, adopted for weight coefficients $\mathrm{d}$, are given in the table. 
In order to overcome the difficulties of obtaining quantitative values of the quality criteria, it was proposed to use point estimates of their main indicators. To assess the quality of the technical level of information systems and ISP, it is proposed to use the following point estimates:

Уом1.1 $=6-$ for the individual preparation;

УОм1.1 $=8-$ for the combined preparation;

yoM1.1 $=10-$ for the centralized preparation;

Table

Values, adopted for weight coefficients d

\begin{tabular}{|l|l|c|c|c|}
\hline $\begin{array}{c}\text { Number of } \\
\text { employees }\end{array}$ & \multicolumn{1}{c|}{$\begin{array}{c}\text { Type of } \\
\text { production }\end{array}$} & $\begin{array}{c}\text { Organizational } \\
\text { maintenance } \\
\left(\mathrm{d}_{\mathrm{OM}}\right)\end{array}$ & $\begin{array}{c}\text { Technical } \\
\text { maintenance } \\
\left(\mathrm{d}_{\mathrm{TO}}\right)\end{array}$ & $\begin{array}{c}\text { Mathematical } \\
\text { maintenance } \\
\left(\mathrm{d}_{\text {MM }}\right)\end{array}$ \\
\hline \multirow{2}{*}{$\begin{array}{c}\text { up to } \\
200 \text { people }\end{array}$} & individual & 3 & 4 & 5 \\
\cline { 2 - 5 } & serial & 0,6 & 0,3 & 0,1 \\
\cline { 2 - 5 } $\begin{array}{l}200-800 \\
\text { people }\end{array}$ & mass & 0,5 & 0,2 & 0,2 \\
\cline { 2 - 5 } & individual & 0,4 & 0,2 & 0,3 \\
\cline { 2 - 5 } $\begin{array}{l}\text { more than } \\
800 \text { people }\end{array}$ & mass & 0,7 & 0,2 & 0,1 \\
\cline { 2 - 5 } & individual & 0,5 & 0,1 & 0,3 \\
\cline { 2 - 5 } & mass & 0,7 & 0,2 & 0,5 \\
\hline
\end{tabular}

УОM1.2 $=5-$ for the regulation of the document application;

yOM $1.2=10-$ for the regulation of the index use;

Уom1.3 $=5-$ for the failure of the information system or ISP with the breach of functioning;

yом1.3 $=8-$ for the failure of the information system or ISP without breaking th functioning and with the reservation of functions by users;

yom1.3 $=10-$ with the reservation of functions in case of the failure of the information system or ISP in the automated mode;

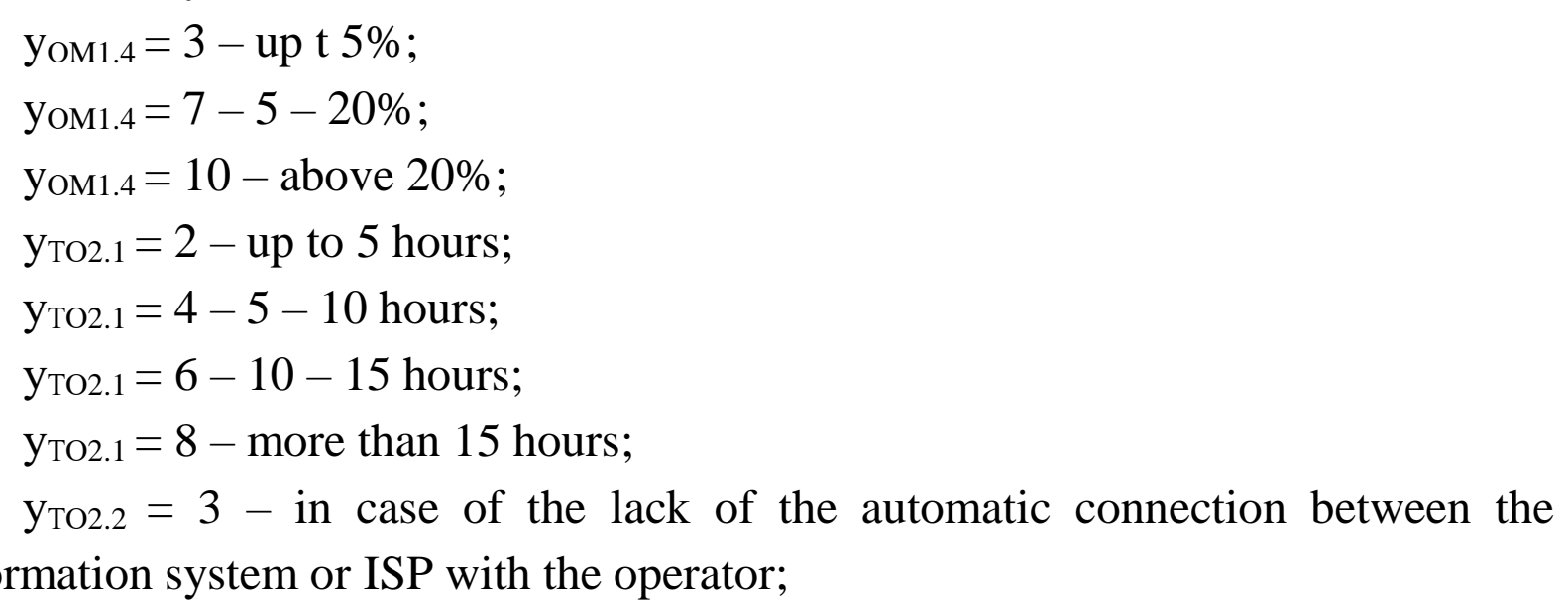


$\mathrm{y}_{\text {то2.2 }}=5-$ in case of the semi-automatic connection of the information system or ISP with the operator;

$\mathrm{y}_{\text {TO2.2 }}=9-$ in case of the automatic connection between the information system or ISP with the operator;

$\mathrm{y}_{\text {то2.3 }}=3$ - the alarm is provided in case of the switching off;

$\mathrm{y}_{\mathrm{TO} .3 .3}=6-$ the alarm is provided in case of regulated display facilities;

т02.3 $=8-$ the alarm is provided in case of response-request devices;

$\mathrm{y}_{\mathrm{MM} 3.1}=5-$ previous generation maintenance;

$\mathrm{y}_{\mathrm{MM} 3.1}=10-$ newest generation maintenance;

$\mathrm{y}_{\text {MM } 3.2}=3-$ for the local solution of the task;

$\mathrm{y}_{\mathrm{MM} 3.2}=6-$ when solving the task using norms;

$\mathrm{y}_{\text {мм } 3.2}=9-$ when solving the task, using the ISP information basis;

$\mathrm{y}_{\mathrm{MM} 3.3}=4-$ using of algorithmic languages;

$\mathrm{y}_{\text {MM } 3.3}=8-$ using of operational systems.

Based on the use of the above indicators together with the weighting coefficients, a formula is introduced to determine the final indicator of the quality of an information system or ISP:

$\mathrm{K}_{\mathrm{ISP}}=\mathrm{d}_{\mathrm{OM}} \times \mathrm{y}_{\mathrm{OM}}+\mathrm{d}_{\mathrm{TO}} \times \mathrm{y}_{\mathrm{TO}}+\mathrm{d}_{\mathrm{MM}} \times \mathrm{y}_{\mathrm{MM}}$

The calculated quality values of an information system or ISP obtained based on the use of formula (4) and the multi-criteria expert system described above can be compared with the initial quality requirements for these products. On this basis, it can be concluded that the developed information system or ISP corresponds or does not correspond to the required level of quality of their functional purpose.

\section{Opinions}

The article describes an approach to the formation of a multi-criteria expert system, which includes a set of criteria and basic indicators, their weighting coefficients and metrics for calculations. With the help of this tool, it is possible to obtain a fairly close to real assessment of the quality of information systems or ISP at all stages of the development and operation of these information products. Of course, the proposed system cannot be considered the only correct tool for assessing the quality of information systems or ISP. It is obvious that with the appearance of more advanced versions of information systems or ISP, the composition of criteria and main indicators, their weight coefficients and metrics for computing will change in accordance with the requirements imposed by users to the functionality of the new version of the information system or ISP. Besides that, it seems to us more appropriate to form a multi-criteria expert system consisting of a number of criteria 
and their main indicators detailing them, with their weighting coefficients and metrics for making calculations in relation to this information system or ISP, taking into account the basic requirements for their functioning, in order to obtain reasonable assessments of the quality of a specific information system or ISP.

\section{Bibliography}

1. Chernikov B.V. Software Quality Management: manual. - M.: PH FORUM: INFRA-M, 2014. - 240 p.

2. Hull E., Jackson K., Dick J., Requirements Development and Engineering. User's practical manual (Second edition). - L.: Springer, 2005. - 240p.

3. Kolos N.V., Ozhog S.V., Iovleva O.V. Research of Method Approaches with the Evaluation of the Efficiency of IT -projects // Herald of the Belgorod University of Cooperation, Economics of Rights 2017. - Ed. 6 (67).

4. ISO/IEC 25010:2011. Systems and software engineering - Systems and software Quality Requirements and Evaluation (SQuaRE) - System and software quality models.

5. GOST R ISO/MEC 25010-2015. Information Technologies. Systemic and Software Engineering. Requirements and Evaluation of the Quality of Systems and Software (SQuaRE). Models of Software and Systems' Quality.

6. Giarratano G., Riley G. Expert Systems. M.: Williams. 2007.

7. Zalyazhnykh V.A., Girik A.V. Expert Systems of the Comprehensive Evaluation of the Safety of Automated Information and Communication Systems. $\mathrm{SPb}$ : ITMO University, 2014. - $136 \mathrm{p}$.

8. Moiseeva T.F. Methods and Means of the Expert Research. - M.: MPSI, 2006. $-216 \mathrm{p}$.

9. Sidelnikov Y.V., Saltykov S.A. Procedure of the Selection of Most Acceptable Kinds of Expert Methods // Large Systems’ Management. 2010. № 30. P. 35-66.

10. Development of Professional Expertise. Toward Measurement of Expert Performance and Design of Optimal Learning Environments / Edited by K. Anders Ericsson. Cambridge University Press, New York, USA, 2009.

11. Kotsuba I.U., Chounaev A.V., Shikov A.N. Methods of Evaluation and Management of Information Systems' Features. Manual. - SPb: ITMO University, 2015. - $264 \mathrm{p}$.

12. Kroutin Y.V. Efficiency of Information Systems and Technologies. Ekaterinburg, 2020. -62 p. 